\title{
Public policy-making and risk profiles: Scandinavian centre-right governments after the turn of the millennium
}

Article

Accepted Version

Arndt, C. (2017) Public policy-making and risk profiles:

Scandinavian centre-right governments after the turn of the millennium. European Political Science Review, 9 (4). pp. 495518. ISSN 1755-7739 doi:

https://doi.org/10.1017/S1755773916000072 Available at https://centaur.reading.ac.uk/72894/

It is advisable to refer to the publisher's version if you intend to cite from the work. See Guidance on citing.

Published version at: https://doi.org/10.1017/S1755773916000072

To link to this article DOI: http://dx.doi.org/10.1017/S1755773916000072

Publisher: Cambridge University Press

All outputs in CentAUR are protected by Intellectual Property Rights law, including copyright law. Copyright and IPR is retained by the creators or other copyright holders. Terms and conditions for use of this material are defined in the End User Agreement.

www.reading.ac.uk/centaur 
Central Archive at the University of Reading

Reading's research outputs online 


\section{Introduction}

While the welfare state literature typically emphasises risk protection as the welfare state's nucleus (e.g. Korpi, 1983; Baldwin, 1990; Esping-Andersen, 1990), recent advances have distinguished social programmes and public policies according to the risks they protect against (Esping-Andersen, 1999; Cusack et al., 2006; Busemeyer et al., 2009; Jensen, 2011, 2012). Life course risks are largely unrelated to class, but occur during the life course and concern risks such as old-age or health, which, in principle, everybody is exposed to. In contrast, labour market risks, such as the risk of becoming unemployed, are typically class- and income-related. This distinction has important implications for policy-makers. Social programmes to protect against life course risks enjoy broad support among the electorate, including the middle class and the median voter as likely and future beneficiaries of those programmes (Busemeyer et al., 2009; Jensen, 2011). Social programmes protecting against labour market risks are less well-entrenched since the median voter and the middle class are not heavily exposed to those risks compared to working class voters, among which such schemes enjoy their broadest support.

The risk profile protected by a programme and the voter coalition that a party represents therefore determine a party's leeway to reform or retrench the different programmes. Representing middle- and high-income voters, right-wing parties have more room for manoeuvre on labour market-related schemes since these risks are underrepresented in the right-wing's electorate. Consequently, retrenchment of unemployment benefits is less hazardous, while the right-wing may even be forced to outspend the left on life course-related schemes to keep the median voter but refrains from retrenching these schemes (Jensen, 2011, 2012).

Moving beyond these stylised assumptions, I examine in this paper what right-wing parties do if the risk profile of their electorate does not correspond to the literature's theoretical expectations; that is, if right-wing parties have gained power with an unusual high share among low-income and 
working class voters and, thus, high risk voters? Do centre-right parties act with bound hands on labour market-related schemes if this is the case?

I argue that centre-right parties that govern with an unusually high support among working class voters are also constrained on labour market-related schemes and not only on life courserelated schemes as the literature would predict. The actual risk profile of their electorates thus matter for the centre-right's latitude on labour market-related schemes. To test this argument, I conduct a comparative case study of two recent Scandinavian liberal-conservative governments' health and labour market policies (2001-2014). By 2000, Danish and Swedish centre-right parties had adapted their electoral messages and were then rewarded among the electorate and expected to engage in policies reflecting the preference structure of their actual electoral coalition, which brought them into power.

In this respect, I show that both liberal-conservative governments pursued similar health policies, but different labour market policies, where the Swedish centre-right government was much more active in reforming the unemployment insurance and cutting unemployment benefits and income taxes. The Danish government had a much higher share of workers in its electorate, partly because of the inclusion of the Danish People's Party in a quasi-coalition. This made larger labour market reforms principally unfeasible in the Danish case whereas its Swedish counterpart had less to fear from direct retrenchment given the weaker support from working class votes.

The study's contribution is therefore twofold. First, it enhances our understanding of how the electorates' risk profile matters for public policies, and it shows that the distinction between labour market and life course-related schemes is valid beyond statistical associations in time-series analysis. Second, it shows that the heroic assumptions on right-wing parties' electorates do not always hold and that analysis of public policy should look at the actual electoral composition of the government(s) under review. This paper proceeds as follows. First, I review the theoretical 
arguments and develop my argument. Afterwards, I discuss the case selection and the crucial difference between the electorates of the Danish and Swedish governments. Then, I analyse the public policy of both governments in view of my arguments. Finally, I discuss the implications of the findings.

\section{Theory}

Early on, the classic welfare state literature had identified one central goal of the welfare state: the protection against risks (e.g. Korpi, 1983; Baldwin, 1990; Esping-Andersen, 1990, 1999). Particularly, the protection of labour against risks stemming from market exposure - the decommodification of labour - was seen as a central task of the welfare state (Esping-Andersen, 1990). This was related to poverty alleviation and redistribution as the welfare state's goals. These arguments fit with arguments from partisan theory according to which parties are expected to pursue public policies that are in the interests of their electoral constituencies (e.g. Hibbs, 1977; Castles, 1982; Schmidt, 1982). These literatures emerged from rather stylised assumptions of the partisan logic around welfare state development and welfare state policies. The left (Social Democrats and labour parties) represented the working class and the lower income strata, while the right (secular liberal and conservative parties) represented the higher income strata, farmers, and business. The left therefore advocated encompassing and generous welfare states, whereas the right preferred lenient welfare states. Continental Christian democratic parties were seen as falling in between by offering welfare policies reflecting a cross-class compromise. The actual arrangement and size of the welfare state originated from the social groups' power resources represented by and through the parties (Korpi, 1983; Esping-Andersen, 1990). While empirical analyses of these arguments have looked at welfare spending, social expenditure, or replacement rates of different schemes (e.g. Kittel and Obinger, 2003; Korpi and Palme, 2003; Allan and Scruggs, 2004; Jensen, 
2010), the concrete partisan logic behind the different schemes at the national level remained somewhat unclear until recently. Policy areas and programmes were treated equally without making more nuanced arguments about which scheme might deviate from the simple logic between a prowelfare left-wing and a welfare-sceptical right-wing (Jensen, 2011, esp. 909ff).

Beginning with Esping-Andersen's (1999) distinction of welfare programmes between labour market- and life course-related schemes, recent advances in the literature have conceptualised the manoeuvre room for parties across different welfare schemes (Cusack et al., 2006; Busemeyer, et al. 2009; Jensen, 2011, 2012). I use these arguments to theorise the expected direction of centre-right policies across different policy areas and to argue why the risk profile of a government's electorate matters for its public policy. In other words, why do similar centre-right governments in similar welfare states pursue different policies in policy areas where they should have similar latitudes? The point of departure here is that different welfare schemes insure different risk profiles, which, in turn, differ by voter groups. Consequently, the room for manoeuvre for a given party varies by scheme and is contingent on the voter groups and, thus, the risk profile it represents.

\section{Labour market-related schemes}

Drawing on Esping-Andersen (1999), Jensen (2012) has distinguished labour market- from life course-related social policies to explain differences and similarities in the policies of left-wing and right-wing governments. Labour market risks stem from labour market participation, such as becoming unemployed or having a work accident. These risks mainly affect working class and lowincome voters, whereas the median voter is less affected by these risks and therefore demands less protection against labour market risks (see also Cusack et al., 2006; Busemeyer et al., 2009). Consequently, the middle class might accept cuts of unemployment benefits, and this is especially the case if this is compensated for by tax cuts. 
According to Jensen (2012), this gives the centre-right more leeway in reforming and retrenching labour market-related schemes than the centre-left since the electoral constituency of the former consists of medium- and high-income voters not strongly affected by labour market risks as long as unemployment is sufficiently low. By implication, centre-right governments that gained power with an unusual high support among working class (and thus high risk) voters should have less leeway in reforming labour market schemes such as unemployment insurance as Jensen (2012) originally assumes. This problem is virulent in our case, since the mainstream Scandinavian centreright parties began to present themselves as 'new labour parties' to expand their voter base with working class voters around the turn of the millennium (Mortensen, 2008: chap. 6; Oscarsson and Holmberg, 2008: 68; Davidsson and Marx, 2013). ${ }^{1}$ If this was a successful vote-seeking strategy, the Scandinavian centre-right should have bound its hands on labour market-related schemes as reforms have become too risky. The electoral slack is then greater compared to a situation, in which the overwhelming majority of working class voters lie outside the bourgeois constituency, if we follow the electoral slack reasoning of Jensen (2012) and Pierson (1994: 19ff). This means that successful mobilisation of working class votes at the election that brought the centre-right to power feeds back into the centre-right's future policy, which is now anxious to maintain the working class support at later elections. A less successful mobilisation strategy might in contrast result in catering to the traditional centre-right voter base. This case differs from the stylised assumptions in recent studies (Cusack et al., 2006; Busemeyer et al., 2009; Jensen, 2011, 2012) and helps us understand why similar centre-right governments pursue different public policies.

In this respect, a high share of working class voters inside the centre-right's electoral coalition means that the centre-right cannot engage in substantial reforms of ordinary unemployment benefits and other labour market policies benefiting ordinary wage-earners, especially blue-collar workers.

\footnotetext{
${ }^{1}$ This is however not limited to the Scandinavian centre-right but also relates to other secular conservative or liberal parties such as the Dutch VVD, the New Zealand National Party, and the Finnish Conservatives, which have broadened their voter base.
} 
In this situation, any cutbacks are targeted on labour market outsiders such as social assistance recipients, long-term unemployed, or people with insufficient contribution records. These groups, first, lay out the centre-right's electoral coalition and, second, are perceived as the most underserving groups for social benefits together with immigrants (van Oorschot, 2006; Winter, 2006). The latter is reinforced when we consider that working class voters have strong deservingness perceptions to which a centre-right government with high working class support has to cater. Consequently, we would expect that any cutbacks are strategically targeted at social assistance recipients, long-term unemployed, immigrants, and people with insufficient contribution records if the centre-right governs with unusually high working class support, while ordinary bluecollar workers are not subject to fundamental retrenchment attempts. On the other hand, if the centre-right gained power without strong working class backing (or failed to mobilise this target group), it will still pursue policies that cater to the traditional core constituency, which implies cutbacks on unemployment insurance.

\section{Life course-related programmes}

In contrast to labour market risks are life course-related risks independent of class or income and concern risks such as health or old-age which every voter is essentially exposed to. Only the very well-off can afford private health care through their entire life course, while every other voter group from the lowest income voters to the upper middle class is interested in a public risk-pooling scheme (Jensen, 2011: 912f). This has important implications for policy-makers' room for manoeuvre. Jensen $(2011,2012)$ has argued that existing universal health care insurance effectively binds the centre-right's hands in its policy ambitions because the middle class and the median voter are covered by universal health care. This makes sweeping reform or outright privatisation of health insurance electorally very hazardous for all parties. While the left representing low- to middle- 
income voters is assumed to maintain these schemes, the only feasible policy-seeking solution for the right is marketization through compensation. Accordingly, the right's public spending on universal health care is expected to be at level with social democracy or even higher, whereas private health care solutions such as tax rebates for private insurance schemes are introduced incrementally to cater the traditional core constituency without taking anything away from other voters (Jensen, 2011: 914f).

This constraint is even stronger than in Jensen's (2011) highly stylised assumptions if the centre-right has low-income or low-class voters in its electoral coalition since these have even more to lose than the middle class. I therefore expect the centre-right in countries with universal health care insurances to follow these trajectories and to stay away from any sweeping reforms or cutbacks. In contrast, they are expected to maintain high spending levels and introduce some marketization incrementally to pursue some limited policy-seeking to please some centre-right core voters. Similar logics can be expected for pension policies which are beyond the scope of this paper. Summing up, the literature's distinction between schemes that protect against labour market versus life course risks is generally helpful to analyse the policies of secular centre-right governments. Moving beyond the stylised assumptions on the centre-right's electorates and its left opponents, however, requires accounting for the actual risk profiles. As the two Scandinavian centre-right coalitions under review tried to expand their voter base with working class voters, their hands might not only be bound on schemes protecting life course risks, but also on labour market policies. Understood in a non-deterministic manner, I therefore expect that the policies on labour market risks vary with the actual share of working class votes gained. A high working class support implies no substantial reforms of the ordinary unemployment insurance, and any cutbacks are frontloaded at (undeserving) working-class outsiders. As to life course risks, I expect that, in general, no sweeping reforms of universal schemes such as health are pursued. Nevertheless, there 
may be windows of opportunities that allow the centre-right to engage in stronger policy-seeking than the arguments made would expect. ${ }^{2}$

\section{Research strategy and case selection}

I apply a most-similar-systems design to analyse the importance of the centre-right electorate's risk profile and compare the recent liberal-conservative governments in Denmark (2001-2011) and Sweden (2006-2014) on one life course-related programme (health) and one class-related programme (labour market policy, unemployment insurance in particular). ${ }^{3}$ These two schemes are commonly used to exemplify the differences between life course risks and labour market risks (e.g. Allan and Scruggs, 2004; Jensen, 2011, 2012). The analysis of health will be kept shorter since the theoretically interesting variation between the two countries occurred on labour market policy.

Both countries have universal and tax-financed welfare states where the health care insurance includes the middle class and median voter as the (future) beneficiary. The unemployment insurance is voluntary and union-administered. Since the unemployment insurance can be affected by changes in income tax legislation in both countries, I also include relevant changes in income tax legislation that occurred in the period under review. Given that the unemployment rates remained below 10 percent in both countries during the period of study (see OECD 2014), the risk of unemployment can be expected to be a mainly class- and income-based risk that does not strongly affect the middle class, in line with Jensen's (2012) assumption.

Accordingly, the two countries' welfare states strongly correspond to the arguments distinguishing the political logics of labour market risks from life course risks and should allow a rather strong test of the theoretical propositions. Similarly a number of potential rival explanations

\footnotetext{
${ }^{2}$ Particularly, majoritarian electoral systems might provide these windows of opportunities more often (e.g. the split opposition during Thatcher's governments), while the electoral safety margin in PR systems is usually smaller. Accordingly, my arguments should be particularly applicable to PR systems, while majoritarian systems might provide somewhat different scope conditions.

${ }^{3}$ A similar analysis for pensions yielded similar patterns as for health and is available on request.
} 
given the similarity of the two countries' political systems can be isolated (PR, unicameral parliamentary systems with multiparty systems and strong corporatist traditions with similar institutional veto players). To test the argument that the centre-right's risk profile matters for labour market-related schemes, the governments' coalitions had one crucial difference: the risk profile of the electorate that brought them to power. This is also reflected in the composition of the governments at the macro-level, as outlined below.

The Danish and Swedish centre-right coalitions had been the first longer-lasting, pure rightwing governments in Scandinavia for decades. In Denmark, the Liberals and the Conservatives held office after the 2001 election, while the Danish People's Party (DF) delivered the parliamentary support for the formal minority government and supported all budgets between 2001 and 2010. The Danish case thus reflects a legislative coalition with a pure centre-right parliamentary majority that was used throughout the whole period (the so-called VKO coalition). ${ }^{4}$ In Sweden, the centre-right parties consisting of the conservative Moderate Party, the Liberal People's Party, the agrarian and pro-business Centre Party and the small Christian Democratic Party agreed on a formal cooperation called the Alliance (Alliansen) by 2004 (Dagens Nyheter, 2004) that constituted a pre-electoral coalition in the 2006 and 2010 election campaigns. Accordingly, both cases represent two fixed centre-right (legislative) coalitions that lasted at least two terms. ${ }^{5}$

Both coalitions had been led by the bourgeois mainstream parties in the two countries, the Danish Liberals (Venstre) and the Swedish Conservatives (Moderaterna). These two parties traditionally adhered to market-liberalism and lean welfare states but failed to ensure centre-right majorities despite good election results or even experienced bitter and/or severe electoral losses

\footnotetext{
${ }^{4}$ Typically, centre-right governments in Denmark and Sweden had been short-lasting until the turn of the millennium or were characterised by frequent removal or withdrawal of coalition parties and government reshuffles as in the case of the Swedish non-socialist governments (1976-1982) or the various centre-right minority cabinets in Denmark (19821993). The latter also lacked a parliamentary majority for most of the period and, in contrast to VKO, depended on centre parties.

${ }^{5}$ After the 2010 election, the Swedish coalition sometimes depended on the support of the Green Party or the Sweden Democrats as this election yielded a hung parliament, in which the Alliance only received a plurality.
} 
with their market-oriented stances and anti-welfare state rhetoric in elections around the turn of the millennium (Denmark 1998, Sweden 2002). As a response to the losses, the parties adapted their electoral strategies and began to target working class voters outside their traditional core constituency. The goal was to make future right-wing governments possible and not to lose elections because of the parties' wide-spread anti-welfare image (Lindbom, 2008; Mortensen, 2008). Venstre declared at the 1998 party congress that they were the defender of the man in the street and the party now overhauled its strategy by committing itself to the Danish welfare state, dropping all plans of sweeping tax cuts and promising to keep the level of public spending (Mortensen, 2008: 111-114).

The Moderates in Sweden adopted their electoral message by 2005 as the party committed itself to more spending on health and education and more pragmatic tax policies. In contrast to Venstre, the Moderates proposed cutbacks of unemployment benefits that closely mirrored the reforms described below. The same goes for employment-related tax reforms, which were proposed in 2005. However, despite all attempts to peel of the anti-welfare image, the Moderates' goal was to realise lower taxes, while its Danish counterpart adopted the tax stop principle to signal ideological moderation.

Both parties therefore adopted their electoral message in a Downsian sense to broaden its electoral support in a first step. Venstre's and the Moderates' new policy became increasingly successful as the polls indicated rising support for both parties in the run-ups for the 2001 and 2006 elections, respectively, with the Danish Venstre now competing at eye level with the Social Democrats among working class voters (Mortensen, 2008: 159; Oscarsson and Holmberg, 2008: 25-38). Consequently, both parties gained office in a centre-right coalition in 2001 (Denmark) and 2006 (Sweden) in a second step. However, while both parties aimed at broadening their voter base with working class votes, the actual working class support when the governments took office 
differed considerably (see Table 1). With the 2001 election, the Danish right bloc gained a majority among working class voters, which was maintained at the 2011 election (Andersen, 2003; Arndt, 2013; Stubager and Hansen, 2013). On the contrary, the share for the Social Democrats was the lowest for decades in the 2001 election and did not recover substantially afterwards since a great number of their working class voters were absorbed by the Liberals and the Danish People's Party.

\section{[TABLE 1 ABOUT HERE]}

In Sweden, the Moderate Party and its Alliance partners' actual gains among working class voters in the 2006 election had been more limited (Oscarsson and Holmberg, 2008: 316). In contrast, the Moderate Party's gains were most pronounced among middle class voters, higher public servants, and urban voters from Stockholm. The raw numbers in Oscarsson and Holmberg's appendix (2008) demonstrate that some of the working class gains for the Moderates in 2006 simply signal a reallocation of existing working class in the right bloc. ${ }^{6}$ In contrast, the support for the Swedish Social Democrats among workers did not decline as dramatically as in the Danish case (see Oscarsson and Holmberg, 2008: Appendix A).

In a third step, this means that both parties are expected to implement policy packages resembling the different compositions of their electorates (see Häusermann, 2010 for a similar point on Continental European pension policies). Given the considerably lower working class support for the Swedish centre-right, I expect the Alliance to have more latitude in reforming labour marketrelated schemes since the electoral hazard is simply more limited here, while the Danish centreright had too many working class voters, making sweeping reforms on labour market-related

\footnotetext{
${ }^{6}$ This is not to say that the Moderates' or the Alliance's new profile was not successful among working class voters since the Moderates' results in the 2006 and 2010 elections mark their best performances among the working class ever (Forsberg et al., 2011: Table A12). Nevertheless, their shares remained substantially lower compared to Denmark, where the elections since 2001 revealed centre-right majorities among the working class, with the Liberals outperforming the Social Democrats among manual workers.
} 
schemes unfeasible. ${ }^{7}$ Concerning life course-related risk schemes (health), I expect similar policies of both governments given the electoral threat of reforming the well-entrenched universal schemes. Nevertheless, the Swedish government may have had slightly more leeway to implement some minor cuts as their workers' share was lower.

\section{Analysis}

\subsection{Health}

\section{Denmark}

The Danish centre-right government's health policy has already been analysed by Jensen (2011), and I therefore summarise and update his findings. The Danish centre-right came to power with the 2001 election, especially after the Liberal Party campaigned aggressively on the health issue and criticised the Social Democratic government for the long waiting lists for hospital treatment (e.g. Thobo-Carlsen, 2001). Accordingly, the Liberal Party (or the right bloc in general) managed to steal issue ownership over health from the Social Democrats, the traditional issue owner, in the 2001 election (Andersen, 2003).

In office, the centre-right government increased public health care spending between 2002 and 2011, and this goes both for total health care spending as well as health care spending as share of GDP. This was associated with an increase in the number of jobs in the health care sector (Jensen, 2011: 921). The sickness benefits' replacement rate of 90 percent was left untouched (see Table 3). While certainly no retrenchment of the universal health care took place under the centreright government, two measures confirm marketization through compensation as the only feasible policy-seeking strategy (Jensen, 2011). The first concerns the so-called treatment guarantee (Behandlingsgaranti), which gave patients the right to medical treatment in private hospitals or

\footnotetext{
${ }^{7} \mathrm{~A}$ loss of, say, 10 percent of the working class votes thanks to unpopular reforms would weigh much heavier in the Danish case, where every second worker supported VKO.
} 
abroad in case the patient had to wait more than two months (one month after 2007) in the public health system.

\section{[TABLE 2 ABOUT HERE]}

The second measure is an even clearer measure to cater to the bourgeois core constituency as the government introduced tax rebates for employees that enjoy private health care insurances through their employment contract (conditional on all employees in the firm being covered). With this measure, the number of private sector employees with private supplementary insurances escalated, while public sector employees and non-labour force persons with low income were clearly underrepresented in the mushrooming private schemes (Jensen, 2011: 922).

The VKO government's health care policy thus strongly confirms the arguments made above as no retrenchment, but rather expansion, of the public health insurance took place, while targeted measures were to please the traditional constituencies of the centre-right parties without taking away from others.

\section{Sweden}

As its Danish counterpart, the Swedish government did not engage in sweeping retrenchment of the universal health insurance either, but increased public health care spending at a similar pace (see Table 2). However, the Swedish government engaged in some incremental reforms of the eligibility period and calculation of the sickness benefits. Shortly after having gained office, the government withdrew the increase of the maximum sickness benefits introduced by the Social Democratic predecessor government by decreasing the ceiling for the calculation of sickness benefits. This 
meant a moderate decline of the replacement rate of public sickness benefits from 80 to 77.6 percent, which had also been a temporary measure under the Social Democratic predecessor.

In 2008, the eligibility period for the maximum sickness benefits (Sjukpenning) was limited to 364 days within a period of 450 days (Regeringskansliet, 2008: 15). The period could be extended to 550 days after a request in writing, but with a reduced maximum replacement rate of 75 percent instead of 80 percent. Benefit eligibility was also made conditional on tests of working capability. Another reform in 2009 concerned persons who had hitherto drawn unlimited sickness benefits. These persons can now earn money through paid work without having their eligibility to unlimited benefits re-assessed by the Social Insurance Agency (Försäkringskassan). Instead, work income will be offset with the sickness benefits so that the persons concerned do not lose income in total (a free amount applies) (Regeringskansliet, 2008: 15).

Moreover, the Swedish centre-right engaged in more visible marketization of the health insurance. In 2007, the legislation regarding the operation of private hospitals was liberalised since it was made easier to run private hospitals in Sweden. The regions can now outsource health care services to private providers without demanding that the enterprises will be run non-profit or exclusively with public financing (Prop. 2006/07:52). The requirement that each region has to run at least one public hospital was abolished, too.

Similar to its Danish neighbour, the Swedish centre-right government introduced free choice of hospitals to the patients. The right to choose freely between providers was later extended to care, while every region was made responsible to offer a free choice between different providers (SFS, 2009:140). One ambition was to reduce the waiting time for the patients and to enhance the competition between municipal, regional, and private health care providers and hospitals since private enterprises could register as providers, too. As in the Danish case, a treatment guarantee (Vårdgarantin) to limit the patients’ effective waiting period was introduced (SFS, 2010:243). 
Another measure concerned the ending of employers' co-financing of sickness benefits after the second week on benefits. This was obviously targeted at the business constituency of the centreright parties but was not a cutback for other groups. In sum, both governments performed a similar marketization through compensation since escalating health care expenses compensated for liberalisation without engaging in any outright fiscal retrenchment. Some reforms in Sweden signalled clearer marketization and incremental cutbacks, but the overall expectations were confirmed.

\subsection{Labour market policies and unemployment benefits}

\section{Denmark}

In general, the Danish centre-right government did not make any fundamental reforms of the unemployment insurance until 2010 when the leadership had changed and the economic crisis was raging. The maintenance of the status quo on unemployment insurance was also promised by the upcoming Prime Minister Anders Fogh Rasmussen in the party leaders' debate before the 2001 election. Moreover, both large reform packages implemented under the VKO government that concerned the unemployment insurance and the ordinary unemployed were compromises with the Social Democrats (Andersen, 2011: 206f). In late 2003, VKO tried to initiate cutbacks of unemployment benefits worth 800 million DKK. These reforms were withdrawn for electoral reasons as leading politicians of Venstre and DF scrutinised their effects on their own electorates and did not want to follow the proposals of the Minister of Labour Affairs who now was left alone (see Ditlev and Maressa, 2003; Maressa, 2003). Consequently, the then Minister of Labour Affairs, Claus Hjort Frederiksen, said that VKO would not introduce any changes to the ordinary unemployment benefits before the 2005 election. He passed the buck for future changes to a "Welfare Commission" that was to come up with suggestions that technically could not be 
implemented before the fiscal year 2007 (Maressa and Svane, 2003). This deliberate choice not to tackle the ordinary unemployment insurance in view of the centre-right's voter coalition was later made public by Minister Frederiksen. In an interview, he stated that the Liberal-led government could not tighten the eligibility or generosity of the unemployment insurance on its own and that one had to wait for a Social Democratic government to do so (Hardis, 2006). Frederiksen also rejected the proposal of the "Welfare Commission" in 2005 to reduce the eligibility period of ordinary unemployment benefits from four years to two and a half years (Bonde, 2005), and this promise was kept until 2010 (see below). This signals awareness of the Danish centre-right constituency's risk profile since 2001 and thus the centre-right's room for manoeuvre. In this regard, the government also introduced a special tax credit (Beskaftigelsesfradrag) for wageearners in 2004 to increase the income difference between ordinary wage-earners and people who exclusively draw on passive welfare benefits such as social assistance, while sweeping tax cuts for the well-off were ruled out before the 2005 election (Ritzau, 2004).

While maintaining the status quo on the ordinary unemployment benefits, the VKO coalition also implemented some changes. The so-called labour market reform package IV (2002) and the welfare reform agreement (2006) introduced tighter activation rules, tighter eligibility criteria, and more surveillance of people drawing regular employment benefits, but abstained from any fiscal retrenchment such as lower replacement rates, shortened eligibility periods, or changed membership rules for the unemployment insurance (as in the Swedish case analysed below).

In contrast, most reforms were targeted at labour market outsiders and (non-western) immigrants since the government introduced a lower social assistance rate (starthjalp) for people that have lived outside Denmark for more than seven out of the last eight years (Andersen, 2007: 263). Similarly, a ceiling on maximum social assistance benefits for families (kontanthjaclpsloft) and a requirement of 300 hours of work within 24 months for married social assistance recipients to 
keep the spouse's social assistance were introduced. These measures would mean a monthly cutback of more than 1,500 DKK (around $200 €$ ) for families without any regular working income (Beskæftigelsesministeriet, 2004). They clearly did not concern ordinary unemployed, who were protected through the unemployment insurance funds. In this regard - and fitting to deservingness perceptions among blue-collar workers mentioned in the theory section above - the Danish People's Party's spokesman for labour market affairs, Bent Bøgsted, claimed that the starthjoelp is targeted at people that come from outside Denmark, while the ordinary benefits are meant for people who have contributed for a longer period of time before they lost their job (Ritzau, 2005). This fits with the expectation that a centre-right government with strong working class backing will refrain from cutbacks that concern ordinary blue-collar workers and instead target cutbacks at labour market outsiders.

The only cutback made until 2010 was indirect as the tax reform of 2009 gradually reduced the deductibility of union membership fees from 33 per cent in 2009 to 25 per cent in 2019 (Andersen, 2011: 193, 2012: 351). This made the membership in the union-administered unemployment funds somewhat more expensive and might reduce the universality of the scheme in the long run. However, the generosity and universality of the unemployment insurance scheme in Denmark was not seriously reduced by the centre-right government which targeted cutbacks at labour market outsiders instead.

\section{[TABLE 3 ABOUT HERE]}

The situation changed in 2010/11 when Lars Løkke Rasmussen had replaced Anders Fogh Rasmussen as Prime Minister and Venstre leader and the financial crisis had made its impact on Denmark's fiscal situation. In spring 2010, the government in a desperate attempt announced its first direct retrenchment of the unemployment insurance as the eligibility period was halved from four to two years and the requalification period for unemployment benefits was increased from six 
to 12 months while the replacement rate was not touched. This meant that many ordinary wageearners who had become unemployed during the recession now risked losing their benefits with tougher conditions to requalify, and this concerned 33,900 persons by $2013 .{ }^{8}$ The reform was supported by the oppositional Radical Liberals, so again, policy-seeking with a split opposition. However, in combination with an early retirement reform, this reform was one reason for the loss of the 2011 election as the VKO coalition lost support among working class voters to the benefit of the Social Democrats (Stubager et al., 2013); an indirect proof that these measures conflicted with the electoral risk profile. ${ }^{9}$

\section{Sweden}

Despite having campaigned as Sweden's "new workers' party", the Moderates and the Alliance already announced cutbacks of the unemployment benefits in 2006 but were nonetheless able to win ownership over the unemployment issue (Davidsson and Marx, 2013). In contrast to its Danish counterpart, who pointed to the electoral considerations of labour market reform, Sweden's Labour Minister, Sven Otto Littorin (Moderates), explicitly stated that the unemployment insurance should be a basic income scheme rather than a scheme that compensates for 80 percent of one's former income for the majority of the people and that no more money should be spent on unemployment benefits (Forssblad, 2008).

Consequently, shortly after the new government had taken power, the maximum unemployment benefits were reduced from 730 to 680 SEK per day. Moreover, the replacement rate of unemployment benefits of 80 percent is only kept for the first 200 days, after which it decreases

\footnotetext{
${ }^{8}$ Since the actual effects of the shorter eligibility were to materialise in 2012/13 when a social democratic government was in power, not all Danes attributed the blame to VKO, but perceived the social democrats to be responsible for many unemployed falling back on social assistance or losing all public support because of the eligibility criteria for social assistance.

${ }^{9}$ It is beyond the scope of this paper to analyse whether this decision produced net gains or losses in the late campaign before the 2011 election and whether Venstre substituted some lost working class votes with middle class gains from other parties.
} 
to 70 and later 65 percent after more than 200 and 300 days of unemployment, respectively (Regeringskansliet, 2007: 42f; Sjöberg, 2011: 214). A longer duration applies for unemployed with dependent children, where the period for the 70 percent benefits is extended to 450 days. After the expiration, unemployed persons are transferred to the Job and Development Guarantee, a new ALMP scheme according to which participants are entitled to a minimum benefit of 223 SEK (320 for union members) per day. Further measures of the 2007 legislation package concerned stricter suitability criteria and stricter calculation rules for the unemployment benefits (see Sjöberg, 2011 for an overview). In 2008, the number of waiting days for the unemployment benefits was increased to seven.

The eligibility criteria for the unemployment insurance had also been tightened as the possibility to qualify for benefits (including the basic allowance) through study was abolished (Sjöberg, 2011: 213, 217). Another way of tightening the eligibility criteria for unemployment benefits was to significantly increase the (originally very low) membership fees for the unionadministered insurance funds, and this was by far more drastic and abrupt than gradually reducing the tax deduction as in the Danish case. ${ }^{10}$ Accordingly, the share of insurance fund members decreased by 13 percent within two years, and thus, the share of unemployed eligible for incomerelated unemployment benefits dropped substantially to 40 percent by 2012 (see Sjöberg, 2011: 217ff; SO, 2012; Kjellberg, 2013).

Another measure seemed to cater to low and middle incomes since the Swedish centre-right followed its neighbour in implementing tax credits for wage-earners (Jobbskatteavdraget). Five reforms from 2007 to 2014 lowered the tax rates for low to middle incomes (Regeringskansliet, various years) and were aimed at increasing the distance between working and transfer incomes as in the Danish case. However, and in contrast to the largely revenue- and distribution-neutral Danish

\footnotetext{
${ }^{10}$ Sjöberg (2011: 214) states that the average monthly union fee increased from $9 €$ in 2006 to $30 €$ in 2007 , while the differences between the minimum and maximum fees more than sextupled.
} 
reforms, the Jobbskatteavdrag had side-effects as it effectively reduced the replacement rates of ordinary unemployment benefits (Palme, 2012: 8) and was financed by abolishing the right to deduct union membership fees, which were raised substantially (as outlined above). These measures were justified by the argument that everyone would be better off since the corresponding tax relief targeted at low and middle incomes gave overcompensation for the extra union membership fees. This may be a questionable justification since the tax breaks and lower union membership fees benefited the wage-earners with low unemployment risks, while classical working class occupations such as metal workers paid much higher unemployment benefits or were even forced to leave the union for financial reasons (see Kjellberg, 2013, 2014). ${ }^{11}$ This clearly supports the argument that the Swedish government pursued more clear centre-right policy-seeking compared to the Danish case as they included retrenchment, and not only tax breaks and the reforms matched the theoretical expectations since they had a clear class profile.

Furthermore, even though this measure was withdrawn in 2014 (Prop. 2013/14:1), it marked a much clearer attempt in de-universalising and retrenching the unemployment insurance compared to what we saw in the Danish case as 500,000 persons dropped out of the insurance funds after the Alliance's victory in 2006 (Kjellberg, 2013: 11, 20). In Denmark, only 33,900 persons lost their entitlements because of the shorter eligibility period implemented in 2013 as outlined above. The then Swedish Labour Minister, Sven Otto Littorin (Moderates), defended those measures and their motivations in various interviews, while his Danish colleague, Claus Hjort Frederiksen, distanced himself and his Liberal Party from such more far-reaching measures (Hardis, 2006; Houmark Andersen, 2007; Forssblad, 2008; Lönegård, 2009). Confronted with the question from the OECD economist for Denmark and Sweden, Jens Lundsgaard, why it was so difficult for a centre-right government in Denmark to engage in reforms of unemployment benefits just as the Swedish centre-

\footnotetext{
${ }^{11}$ One reviewer pointed out that the Swedish policies were more symbolically addressed to the working class, while their real effects benefited the centre-right's core constituency more.
} 
right did, Claus Hjort Frederiksen responded that his government would not touch the unemployment benefits in Denmark before and after the next election without consent of the social democrats (Houmark Andersen, 2007). The rationale for keeping the ordinary unemployment system was to maintain the Danish flexicurity system, while his Swedish colleague Littorin explicitly advocated a system change, where the unemployment insurance would remain as basic insurance to be topped up with private supplementary insurances (Forssblad, 2008).

Littorin also clearly stated that the Moderates' labour market policy should be regarded as a clear alternative to the policies of the Swedish Social Democrats - a clear difference to the consensus-seeking Danish attempt. The Moderates' policy paper for the 2010 election formulated the strategy to contrast the choice between the centre-right government's "working line" and a leftwing "expanded passive benefit system" (Moderaterna, 2009: 54). The paper contains a commitment to further labour market reforms to increase labour supply and defends the cutbacks made in the 2006-2010 term since the cutbacks would increase the incentives to re-enter the labour force (Moderaterna, 2009: 52-55, 63-64). This implies no adaption of the electoral strategy to gain working class votes or to cater to voters who had lost their eligibility to unemployment benefits since 2007.

Similarly, the Danish minister explicitly and implicitly referred to electoral considerations as motivation for the government's cautious politics in the interviews, while no statements were made by the Swedish minister or government in general pointing to deliberate choices made by the two governments that incorporated the different risk profiles of their electorates.

Summing up, in contrast to its Danish counterpart, but in line with the expectations, the Swedish centre-right engaged in active retrenchment of the unemployment insurance from the beginning, making the scheme less generous and less universal for average wage-earners. This also included direct fiscal retrenchment of the ordinary unemployment benefits, which was not the case 
in Denmark (until 2010/11), where all direct cuts were targeted at outsiders, and other measures were far more incremental.

\section{Corporatism and organised interests as rival explanation}

My findings that the Swedish centre-right government was more active in retrenching the unemployment benefits because of the different risk profile of its electorate might compete with a rival explanation that corporatism and more generally organised interests played a decisive role for the diverging paths of the two centre-right governments under review. I argue here that this is not the case and that the Danish VKO actually had more leeway for reforms in terms of a veto player logic.

First, recent analyses on the development of corporatism and interest group involvement in legislation in Scandinavia (Christiansen et al., 2010; Öberg et al., 2011) showed that interest groups such as unions or employer associations are more strongly involved in legislation in Sweden than in Denmark. Moreover, the involvement of interest groups in preparation and implementation of legislation after 2000 has weakened in Denmark but not in Sweden (Christiansen et al., 2010: 32):

All together, the old tradition of including interest organizations in the preparation of public policy through membership of commissions has declined in all three Scandinavian countries, but more so in Denmark and Norway than in Sweden. The decline is found in all policy sectors, inclusive of labour market, agriculture, and industry (...).

Similar conclusions on the weaker corporatist involvement in public policies in Denmark are also reached in Öberg et al. (2011). 
Second, both centre-right governments implemented similar long-sighted administrative changes of the unemployment insurance. The centre-right governments de facto removed the unions' influence on the local employment services and the administration of the ALMPs to reduce the power resources of the unions in the long-run (for Denmark, see Klitgaard and Nørgaard, 2014; for Sweden, see Berglund and Esser, 2014, esp. p. 74). The Danish government did not exploit the larger room for manoeuvre in labour market policies gained through the administrative changes of the unemployment insurance between 2001 and 2010/11, but saw these as fulfilment of long-term policy goals per se. In contrast, the Swedish Alliance fulfilled these long-term policy goals, but also used the administrative changes as means to achieve further goals: cutbacks of the unemployment benefits for ordinary wage-earners outside their electoral coalition and reforming the structure of the Swedish unemployment insurance.

In sum, I do not regard veto players and corporatism as a strong alternative explanation to my findings. Institutional veto players were actually stronger in Sweden in the period under review and made reforms less feasible from a veto player logic (compared to Denmark). In this vein, it was in principle easier to circumvent corporatism and unions for the VKO if it had wished to do so compared with the Swedish Alliance. 


\section{Discussion}

My starting point was the different logics of life course risk- and labour market risk-protecting schemes. While life course risks concern almost every voter, labour market risks are more virulent for low-income and working class voters. For this reason, centre-right parties representing middle class and middle- to high-income voters have more room for manoeuvre to retrench and reform labour market-related programmes (Jensen, 2011, 2012). However, these stylised assumptions are questioned if the centre-right gains power with an unusually high support among working class and low-income voters. I argued that in this case, the centre-right is also constrained on labour marketrelated schemes because retrenchment is more risky than the literature originally assumed.

I therefore examined what centre-right governments do when constrained by the composition of its voter groups. This was analysed by comparing recent Danish and Swedish liberalconservative governments. The Danish centre-right's electoral success after 2000 was in contrast to the Swedish centre-right's based on strong working class support which implied a reduced room for manoeuvre on labour market-related schemes compared to its Swedish counterpart.

The analysis of the two governments' policies in the areas of health and labour market policies largely confirmed the expected similarities and differences in the policies. Some policies of the Swedish Alliance reflected those of the Danish centre-right with a delay of 3-5 years (e.g. private providers and treatment guarantee in the health sector and supplementary benefits for pensioners with low incomes). The common denominator for both centre-right governments was not to touch the universal life course-related schemes (health and pensions) to secure support among voters that may defect to the Social Democrats.

Other policy areas deviate substantially as the Swedish government made direct cutbacks of the unemployment insurance benefits, whereas their Danish counterpart largely maintained the status quo and targeted all direct cutbacks at labour market outsiders until the crisis package in 
spring 2010. Thanks to its substantially lower share of voters exposed to labour market risks, the Alliance could implement harsher reforms and cutbacks of unemployment benefits and therefore engage in stronger policy-seeking compared to the liberal-conservative governments in Denmark when it comes to class-related schemes. The Danish centre-right did not do anything for almost a decade on labour markets schemes as every second working class voter had supported centre-right parties since 2001. Until 2010, the Danish centre-right did not enact a single reform alone, but always acted in cooperation with at least one opposition party during a window of opportunity to avoid blame, whereas the Swedish pendant made cutbacks without consent of other parties.

These findings have a couple of implications. First, the distinction between life cycle and labour market risks found in previous time-series regression analyses is also at work, when examining public policies at the country-level through comparative case studies. This study thus confirms that schemes protecting against life course risk are still an effective constraint as the two centre-right cabinets examined have rarely dismantled the universal health care or pension schemes, but partly made them even more generous. Future studies might apply a similar logic for the study of redistribution and taxation on the welfare state's revenue side since Sweden saw rising intralabour income inequality and relative income poverty in the period under review and surpassed Denmark on these indicators (OECD, 2013b; Kjellberg, 2014).

Second, the arguments and findings of this study point to a more nuanced distinction of life cycle and labour market risks. Partisan politics theory should re-think its too heroic assumptions of the party families' electoral risk profile when it comes to comparative analysis of public policies. Because the actual composition of the electorates of centre-left and centre-right governments do no longer map nicely on the income or class scale, as often assumed in the traditional partisan theory (Hibbs, 1977; Castles, 1982; Schmidt, 1982), analysis of public policies should begin with the actual social composition of a government's electorate to formulate more realistic propositions of 
why governments promote certain public policies and construct more complex policy packages (see Häusermann, 2010 for a similar point). This helps explaining seemingly surprising outcomes such as a decade of status quo maintenance in Danish unemployment insurance under a pure centre-right majority and clarifies the conditions under which centre-right parties overcompensate or engage in retrenchment.

In this respect, I believe that the findings of this case study can be generalised to explain other centre-right governments' policies accordancing to their risk profile. First, a comparison between centre-right coalitions in Austria and Germany reveals similar patterns in terms of reforming labour market-related schemes. The new right FPÖ gained office in 1999 in a coalition with the Christian Democratic ÖVP on the basis of strong support among blue-collar workers. This government with the FPÖ as the driving force then initiated some sweeping labour market reforms and reforms of the unemployment insurance. Consequently, the FPÖ had reformed against its own electoral coalition and was severely punished at the 2002 election. Compared to the Danish case discussed above, this case is therefore an illustrative counterfactual for a right-wing party with a large working class backing that engages in reform of labour-market related schemes and then loses considerably. The CDU in Germany provides a case where a centre-right party has moderated its labour market policies after an unexpected defeat in 2005, somewhat similar to the Danish Venstre in and after 1998. Since 2005, the CDU has outperformed the SPD among working class voters and refrained from any significant cutbacks on labour market schemes in the 2009-2013 centre-right coalition with the FDP, even though this coalition had the parliamentary majority to enact those reforms. This hesitant stance on labour issues of Merkel's second cabinet thus resembles quite well the policies of the Danish centre-right until the recovery package in 2010 and indicates that the argument travels to other Western European countries applying PR. 
Second, a natural candidate for the applicability of my argument is the Norwegian centre-right government (since 2013) that has a non-trivial working class share in its electoral coalition thanks to the involvement of the Progress Party. Among other factors, this government's electoral fait hinges on the ability to incorporate the actual risk-profile in their public policy strategies. Future studies should therefore enhance our understanding of when the risk profile of partisan electorates matters for public policy outcomes and when partisan differences become blurred because of nonexistent differences in risk exposure.

\section{References}

Allan, J.P. and Scruggs, L. (2004), Political Partisanship and Welfare State Reform in Advanced Industrial Societies. American Journal of Political Science 48(3): 496-512.

Andersen, J. and Andersen, J.G. (2003), Klassernes Forsvinden. In J.G. Andersen and O. Borre (eds), Politisk Forandring. Vardipolitik og Nye Skillelinjer ved Folketingsvalget 2001. Aarhus, Systeme, pp. 207-221.

Andersen, J.G. (2003), Partiernes Image: De Borgerlige Bedst til at Sikre Velfærden. In J.G. Andersen and O. Borre (eds), Politisk Forandring. Vardipolitik og Nye Skillelinjer ved Folketingsvalget 2001. Aarhus, Systime, pp. 151-170.

Andersen, J.G. (2007), Restricting Access to Social Protection for Immigrants in the Danish Welfare State. Benefits 15(3): 257-269.

Andersen, J.G. (2011), Denmark: Ambigous Modernization of an Inclusive Unemployment Protection System. In J. Clasen and D. Clegg (eds), Regulating the Risk of Unemployment. National Adaptions to Post-industrial Labour Markets in Europe. Oxford, Oxford University Press, pp. 187-207. 
Andersen, J.G. (2012), Økonomisk Bæredygtighed - Politisk Usikkerhed. Den Danske Velfærdsstat 1990-2012. Politica 44(3): 339-361.

Arndt, C. (2013), The Electoral Consequence of Third Way Welfare State Reforms. Amsterdam, Amsterdam University Press.

Baldwin, P. (1990), The Politics of Social Solidarity. Class Bases of the European Welfare State 1875-1975. Cambridge, Cambridge University Press.

Berglund, T. and Esser, I. (2014), Modell i Förändring. Landrapport om Sverige. Oslo, Fafo-rapport 2014:10.

Beskæftigelsesministeriet (2004), Notat Vedrørende Kontanthjælpsloftet. Accessed at: http://bm.dk/da/Aktuelt/Pressemeddelelser/Arkiv/2004/0713\%20Notat\%20vedroerende\%20K ontanthjaelpsloftet.aspx

Beskæftigelsesudvalget (2013), BEU Alm.del endeligt svar på spørgsmål 79. Accessed at: http://www.ft.dk/samling/20131/almdel/beu/spm/79/svar/1090490/1302411.pdf

Bonde, A. (2005), Velfærdskommissionen Vil Skære Dagpenge Ned Til To et Halvt År. Berlingske Tidende, 8 December 2005.

Busemeyer, M.R., Goerres, A. and Weschle, S. (2009), Attitudes Towards Redistributive Spending in an Era of Demographic Ageing: The Rival Pressures from Age and Income in 14 OECD Countries. Journal of European Social Policy 19(3): 195-212.

Castles, F.G. (ed) (1982), The Impact of Parties: Politics and Policies in Democratic Capitalist States. London, Sage.

Christiansen, P.M., Nørgaard, A.S., Rommetvedt, H., Svensson, T., Thesen, G. and Öberg, P. (2010), Varieties of Democracy: Interest Groups and Corporatist Committees in Scandinavian Policy making. Voluntas 21(1): 22-40. 
Cusack, T., Iversen, T. and Rehm, P. (2006), Risks at Work: The Demand and Supply Sides of Government Redistribution. Oxford Review of Economic Policy 22(3): 365-389.

Dagens Nyheter (2004), Borgarna Till Val Med Gemensamt Program, 31. August. Available at: http://www.dn.se/nyheter/politik/borgarna-till-val-med-gemensamt-program

Danmarks Statistik (2014), Accessed at: www.statistikbanken.dk/OFF24

Davidsson, J.B. and Marx, P. (2013), Losing the Issue Losing the Vote: Issue Competition and the Reform of Unemployment Insurance in Germany and Sweden. Political Studies 61(3): 505522.

De Svenska Hälsoräkenskaperna 2001-2013 (2015), Available at: http://www.scb.se/nr0109/

Ditlev, N. and Maressa, J.E. (2003), Dagpenge: Fogh Kæmper for Troværdigheden. JyllandsPosten, 19 November, 2003.

Esping-Andersen, G. (1990), The Three Worlds of Welfare Capitalism. Cambridge, Polity Press.

Esping-Andersen, G. (1999), Social Foundations of Postindustrial Economies. Oxford, Oxford University Press.

Forssblad, M. (2008), Arbetsmarknadsministeren: Höjt Tak i A-kassan Kostar För Mycket. Sverigesradio, 11 November 2008. Available at: http://sverigesradio.se/sida/ artikel.aspx ?programid $=83 \&$ artikel $=2435270$

Försäkringskassan (2015), Förändringar Inom Socialförsäkrings och Bidragsområdena 1968-2015. Stockholm.

Forsberg, M., Hedberg, P. and Oscarsson, H. (2011), Väljarnas partier 1956-2010. Rapport 2011:1, Valforskningsprogrammet, Statsvetenskapliga institutionen, Göteborgs Universitet.

Hardis, A. (2006), Interview: Claus Hjort Frederiksen. Weekendavisen, 18 August, 2006.

Häusermann, S. (2010), The Politics of Welfare State Reform in Continental Europe. Cambridge, Cambridge University Press. 
Hibbs, D.A. (1977), Political Parties and Macroeconomic Policy. American Political Science Review 71(4): 1467-1487.

Houmark Andersen, I. (2007), Dagpengereform: Hjort Afviser Svensk Dagpengemodel. Information, 9 January 2007.

IAF (2010), Arbetslöshetsförsäkringen - Ersättningsnivå, Högsta Dagspenning, Genomsnittlig Dagpenning Och Kas/Grundbelopp Från Och Med 1980. Available at: http://www.iaf.se

Jensen, C. (2010), Issue Compensation and Right-wing Government Social Spending. European Journal of Political Research 49(2): 282-299.

Jensen, C. (2011), Marketization via Compensation: Health Care and the Politics of the Right in Advanced Industrialized Nations. British Journal of Political Science 41(4): 907-926.

Jensen, C. (2012), Labour Market-versus Life Course-related Social Policies: Understanding Cross Programme Differences. Journal of European Public Policy 19(2): 275-291.

Kittel, B. and Obinger, H. (2003), Political Parties, Institutions, and the Dynamics of Social Expenditure in Times of Austerity. Journal of European Public Policy 10(1): 20-45.

Kjellberg, A. (2013), Vilka "Hoppada Av” A-Kassan eller Avstod Från Att Gå Med? En Studie Av A-Kassornas Medlemsras. Lund University, Studies in Social Policy, Industrial Relations, Working Life and Mobility.

Kjellberg, A. (2014), Växande Avgiftsskillnader i A-Kassan - Ökad Social Polarisering. Lund University, Studies in Social Policy, Industrial Relations, Working Life and Mobility.

Klitgaard, M.B., and Nørgaard, A.S. (2014), Structural Stress or Deliberate Decision? Government Partisanship and the Disempowerment of Unions in Denmark. European Journal of Political Research 53(2): 404-421.

Korpi, W. (1983), The Democratic Class Struggle. London, Routledge and Kegan Poul. 
Korpi, W., and Palme, J. (2003), New Politics and Class Politics in the Context of Austerity and Globalization: Welfare State Regress in 18 Countries, 1975-95. American Political Science Review 97(3): 425-446.

Lindbom, A. (2008), The Swedish Conservative Party and the Welfare State: Institutional Change and Adapting Preferences. Government and Opposition 43(4): 539-560.

Lönegård, C. (2009), Det Blir Inte Några Ändringar i A-Kassan. Fokus, 2009(36), p. 31.

Maressa, J.E. (2003), Angsten for Vælgernes Dom. Jyllands-Posten, 12 November, 2003.

Maressa, J.E. and Svane, A.M. (2003), Dagpenge: Dagpengene Fredes. Jyllands-Posten, 13 November 2003.

Moderaterna (2009), Framtidsvalet 2010. Moderaterna, Stockholm.

Mortensen, H. (2008), Tid til Forvandling. Venstres Vej til Magten. Copenhagen, Gyldendal.

Öberg, P., Svensson, T., Christiansen, P.M., Nørgaard, A.S., Rommetvedt, H. and Thesen, G. (2011), Disrupted Exchange and Declining Corporatism: Government Authority and Interest Group Capability in Scandinavia. Government and Opposition 46(3): 365-391.

OECD (2013a), Economic Outlook 2013, OECD Publishing.

OECD (2013b), Crisis Squeezes Income and Puts Pressure on Inequality and Poverty. Available at: http://www.oecd.org/els/soc/OECD2013-Inequality-and-Poverty-8p.pdf.

OECD (2014), OECD Employment Outlook 2014, OECD Publishing.

OECD (2015), OECD Health Statistics 2015. Available at: http://www.oecd.org/health/healthdata.htm.

Oscarsson, H. and Holmberg, S. (2008), Regeringsskifte. Väljarna och Valet 2006. Stockholm, Norstedts Juridik.

Palme, J. (2012), Den Nordiska Velfærdsstat og Globalisering. Sverige som Eksempel. Økonomi \& Politik 85(4): 3-15. 
Pierson, P. (1994), Dismantling the Welfare State: Reagan, Thatcher, and the Politics of Retrenchment in Britain and the United States. Cambridge, Cambridge University Press.

Prop. 2006/07:52: Driftsformer för sjukhus. Available at: http://www.riksdagen.se/sv/DokumentLagar/Forslag/Propositioner-och-skrivelser/Driftsformer-for-sjukhus_GU0352/?text=true

Prop. 2013/14:1: Regeringens proposition, Budgetpropositionen för 2014. Finansdepartementet.

Regeringskansliet (2007), Viktigare Lager \& Förordningar Indför Halvårsskiftet 2007. Västerås.

Regeringskansliet (2008), Viktigare Lager \& Förordningar Indför Årsskiftet 2008/09. Västerås.

Regeringskansliet (2013), Viktigare Lager \& Förordningar Indför Årsskiftet 2012/13. Västerås.

Ritzau (2004), Venstre Går Efter Jobfradrag. Ritzaus Bureau, 17. December 2004.

Ritzau (2005), Ingen Starthjalp til Danskere. Ritzaus Bureau, 28. December 2005.

Schmidt, M.G. (1982), Wohlfahrtsstaatliche Politik unter Bürgerlichen und Sozialdemokratischen Regierungen. Ein Internationaler Vergleich. Frankfurt, Campus.

SFS 2009:140: Lag om ändring i hälso- och sjukvårdslagen (1982:763).

SFS 2010:243: Lag om ändring i hälso- och sjukvårdslagen (1982:763).

Sjöberg, O. (2011), Sweden: Ambivalent Adjustment. In J. Clasen and D. Clegg (eds), Regulating the Risk of Unemployment. National Adaptions to Post-industrial Labour Markets in Europe. Oxford, Oxford University Press, pp. 208-231.

SO (2012), Lägesbeskrivning av Arbetslöshetsförsäkringen Våren 2012. Arbetslöshetskassornas Samorganisation, Stockholm.

SO (various years), SO-rapport. Arbetslöshetskassornas Samorganisation, Stockholm.

Stubager, R. and Hansen, K.M. (2013), Social Baggrund og Partivalg. In R. Stubager, , K.M. Hansen and J.G. Andersen (eds), Krisevalg. Økonomien og Folketingsvalg 2011. Copenhagen, Jurist- og Økonomforbundets Forlag, pp. 61-88. 
Stubager, R., Hansen, K.M. and Andersen, J.G. (2013), Krisevalg. Økonomien og Folketingsvalg 2011. Copenhagen, Jurist- og Økonomforbundets Forlag.

Thobo-Carlsen, J. (2001), Venstre Indleder Offensiv. Berlingske Tidende, 8. August 2001.

Van Oorschot, W. (2006), Making the Difference in Social Europe: Deservingness Perceptions among Citizens of European Welfare States. Journal of European Social Policy 16(1): pp. 2342.

Winter, N. (2006), Beyond Welfare: Framing and the Racialization of White Opinion on Social Security. American Journal of Political Science 50(2): 400-420. 